\title{
ВMJ Global Health Strengthening regulatory systems for medicines in a changed world: where do we go from here?
}

\author{
Julie O'Brien (D , ${ }^{1}$ Rebecca Lumsden, ${ }^{2}$ Judith Macdonald ${ }^{2}$
}

To cite: O'Brien J, Lumsden R, Macdonald J. Strengthening regulatory systems for medicines in a changed world: where do we go from here? BMJ Global Health 2021;6:e004680. doi:10.1136/ bmjgh-2020-004680

Received 7 December 2020 Revised 9 December 2020 Accepted 11 December 2020

Check for updates

(c) Author(s) (or their employer(s)) 2021. Re-use permitted under CC BY-NC. No commercial re-use. See rights and permissions. Published by BMJ.

${ }^{1}$ Global Regulatory Policy and Intelligence, Global Regulatory Affairs, Pfizer Healthcare Ireland Dublin, Ireland

${ }^{2}$ Global Regulatory Policy and Intelligence, Global Regulatory Affairs, Pfizer Ltd, Tadworth, UK

Correspondence to

Dr Julie 0'Brien;

julie.obrien@pfizer.com

\section{INTRODUCTION}

National regulatory authorities (NRAs) play a vital role in the regulation of medicines globally. A diverse spectrum of NRAs exists, from those with less well-developed systems to those with well-established, advanced systems. Over the past several decades, great strides have been made to strengthen regulatory systems across the globe. For example, greater harmonisation of technical standards via The International Council for Harmonisation of Technical Requirements for Pharmaceuticals for Human Use, ${ }^{1}$ adoption of WHO initiatives such as Good Regulatory Practices ${ }^{2}$ and the Global Benchmarking Tool, ${ }^{3}$ greater use of digital tools and more international cooperation and collaboration-including regulatory reliance mechanisms-between regulatory authorities. These initiatives are essential because strong regulatory systems streamline the regulatory review and approval process, facilitating access to safe and effective medicines to patients. ${ }^{3}$ Never has this endeavour felt more critical.

In December 2019, the first reports of a new virus began to emerge. Since then, over 60 million people globally have been infected with SARS-CoV-2, and over 1.4 million people have died to date due to COVID-19. ${ }^{45}$ The full societal, cultural, economic and long-term physical and mental health impacts of this pandemic remain untold. As the pandemic has unfolded, the need for effective and efficient regulatory systems globally has never been more important. This is true both to ensure continued supply of existing critical medicines, such as those needed for severely ill patients with COVID-19, for example, anaesthetics, sedatives, anti-infectives, neuromuscular blockers and vasopressors, as well as for streamlined review and approval of new innovative medicines (including but not limited to potential COVID-19 vaccines and treatments).
Summary box

Strengthening regulatory systems for medicines in low-income and middle-income countries is critical to ensure fit for purpose, future-proofed and efficient regulatory systems that facilitate access to safe and effective medicines for patients; this holds true before, during and after the COVID-19 pandemic.

- The COVID-19 pandemic has shone a light on weaknesses in regulatory systems around the globe, such as lack of digital adoption, and has precipitated the implementation of long-term aspirations for regulatory strengthening.

- National Regulatory Authorities around the world have demonstrated an extraordinary ability to adapt, including implementation of new ways of working, to fulfil their role both in relation to continued supply of existing critical medicines and review and approval of new innovative medicines (including but not limited to potential COVID-19 vaccines and treatments).

- Regulatory strengthening measures implemented during the COVID-19 pandemic can enhance regulatory systems more broadly beyond the current health emergency.

The multilayered challenges posed by the pandemic to regulatory systems around the world compel all stakeholders to reflect on how, collectively, we can build on the progress to date to strengthen key areas. Stronger regulatory systems will positively impact all stakeholders, during this pandemic and beyond. While there is no doubt that the COVID-19 pandemic is, so far, the most urgent health emergency of our time, the wider perspective of existing unmet medical needs beyond COVID-19 globally cannot be forgotten. Notably, the WHO's sustainable development goal (SDG) of 'one billion more people enjoying better health and well-being' illustrates this, tracked via 14 SDG indicators as part of the WHO's Thirteenth General Programme of Work. $^{6}$

We have previously published our view on what we believe to be the key pillars of 
regulatory system strengthening. ${ }^{7}$ While the context has changed utterly, some of the regulatory strengthening measures that stakeholders have called for over many years are now being driven by necessity due to the COVID-19 pandemic. In this commentary, we reflect on where we need to go from here in a changed world.

\section{RAPID ADAPTATION}

The COVID-19 pandemic has pressure-tested regulatory systems as never before. Regulators and industry have rapidly deployed innovative regulatory strategies to combat COVID-19, supporting the rapid research and development activities occurring in response to the virus while allowing other ongoing regulatory activities to continue. In parallel, restrictions imposed to curb the spread of COVID-19 have disrupted the traditional functioning of regulatory authorities, with many physically shutting their doors and having to quickly adapt to and rely on a variety of digital tools.

Many NRAs around the globe, particularly in lowincome and middle-income countries, routinely require submission of hard copy legalised ancillary documents (examples of ancillary documents required include Good Manufacturing Practice certificates and Certificates of Pharmaceutical Products (CPPs)). However, NRAs have responded swiftly with innovation, patient centricity and pragmatism in permitting submission of electronic versions in place of hard copy documents. This flexibility has allowed for the continued functioning of regulatory systems without impacting patient safety, and NRAs must be commended for this approach. For example, since March 2020, the European Medicines Agency (EMA) has only issued CPPs that are signed and authenticated electronically, thereby allowing the EMA to continue to be able to provide CPPs during the pandemic. ${ }^{8}$ By and large, NRAs around the globe are accepting these electronic certificates. Since then, Health Canada has also announced a pilot to implement issuance of electronic rather than hard copy ancillary documents. ${ }^{9}$

In the past, many NRAs in Africa and the Middle East required mandatory face-to-face meetings in order to submit regulatory applications. This administrative step did not add value from a scientific or regulatory point of view and often resulted in delays due to backlogs in obtaining appointment slots. COVID-19 restrictions mean such face-to-face meetings are no longer possible, and it is to be welcomed that several regulatory authorities in these regions have moved to virtual meetings.

\section{THE IMPORTANT ROLE OF REGULATORY COOPERATION, WORK SHARING AND RELIANCE}

The health emergency has also propelled international regulatory cooperation, work sharing and reliance into higher prominence. The International Coalition of Medicines Regulatory Authorities has demonstrated the value of regulatory cooperation in their work to 'expedite and streamline the development, authorisation and availability of COVID-19 treatments and vaccines worldwide.$^{10}{ }^{11}$ In addition, the WHO has finalised its Good Reliance Practices guidance to support NRAs in implementing these practices. ${ }^{12}$ A number of stakeholders have also encouraged the use of reliance to expedite global registration of COVID-19 treatments and vaccines. ${ }^{13}$ However, implementation of reliance may play an increasingly important role beyond COVID-19, as NRAs may seek to use reliance to manage any reduction in capacity, or increased backlogs of regulatory procedures, that result from the pandemic. Beyond addressing the current health emergency, one silver lining of the pandemic may be an increase of trust and a greater appreciation for the positive impact that multistakeholder collaboration can have on public health.

\section{DIGITAL AS A NEW REGULATORY MAINSTAY}

The pandemic necessitated a greater use of digital tools in ongoing clinical studies as patients could no longer attend clinic visits and monitors could no longer visit sites due to social distancing measures. This meant that for ongoing clinical studies and vital research to continue, remote monitoring and patient consultations were needed (and in some cases direct to patient delivery of investigational product), and these approaches have become more mainstream as a result. ${ }^{14}$ Additionally, there is a greater need for more rapid data sharing between regulators and for rapid release of review outcomes for COVID-19 treatments and vaccines. The EMA released details of exceptional transparency measures that will apply during the pandemic, and according to industry associations, these principles should be followed by other regulatory authorities. ${ }^{15}$

At a broader level, these developments are also fuelling progress towards new models for sharing information, for example, via digital cloud-based platforms. The opportunity exists to re-engineer the outdated transactional system of submitting electronic versions of paper documents towards filing of data more iteratively. New systems could accommodate new forms of evidence from non-traditional sources such as real-world evidence (eg, patient electronic health records and patient experience data) and apply tools such as machine-based learning and artificial intelligence. ${ }^{16}$ Although this is a long-term journey and initially will be pioneered by more wellresourced regulators, the hope is that such a system can be designed to be scalable for use by all regulators and so the anticipated benefits of streamlined processes, reduced redundancy and rework, and enriched regulatory decision making will ultimately benefit all patients globally.

\section{CONCLUDING THOUGHTS}

The COVID-19 pandemic continues to test the robustness of regulatory systems around the world. It has highlighted the weaknesses in regulatory systems, allowing us to reflect on areas for improvement that are still needed. 
This includes greater investment in digital tools, moving away from non-value add requirements such as for hard copy documents and mandatory face-to-face appointments for submissions, as well as greater resources to ensure a more level playing field for NRAs globally.

The unprecedented levels of collaboration and cooperation between all stakeholders to meet the challenge of COVID-19 demonstrates the importance of international regulatory cooperation, work sharing and reliance. This level of cooperation can be applied to other areas of regulatory strengthening ${ }^{7}$ to address broader unmet medical need that remains beyond COVID-19.

The most challenging periods can result in positive change. We have learnt that this new urgency has caused us to think and act differently and more innovatively. Changes in regulatory systems as a result of COVID-19 may have in fact strengthened those systems, permanently in some cases, to the benefit of patients worldwide. We believe this is not just about what we have learnt so far, or are doing differently right now, but about how we can keep learning and strengthening regulatory systems globally to ensure preparedness for future challenges.

Acknowledgements We acknowledge the review, advice and suggestions received from Pfizer regulatory policy and intelligence colleagues.

Contributors All authors contributed to the development of the commentary. J0 led the overall drafting of the manuscript and the section on rapid adaptation. RL led the drafting of the section on regulatory cooperation, work sharing and reliance. JM led the drafting of the section on digital.

Funding The authors have not declared a specific grant for this research from any funding agency in the public, commercial or not-for-profit sectors.

Competing interests The authors are employees and shareholders of Pfizer and work in global regulatory policy.

Patient consent for publication Not required.

Provenance and peer review Not commissioned; externally peer reviewed.

Data availability statement There are no data in this work.

Open access This is an open access article distributed in accordance with the Creative Commons Attribution Non Commercial (CC BY-NC 4.0) license, which permits others to distribute, remix, adapt, build upon this work non-commercially, and license their derivative works on different terms, provided the original work is properly cited, appropriate credit is given, any changes made indicated, and the use is non-commercial. See: http://creativecommons.org/licenses/by-nc/4.0/.

ORCID iD

Julie 0'Brien http://orcid.org/0000-0001-9301-461X

\section{REFERENCES}

1 The International Council for Harmonisation of Technical Requirements for Pharmaceuticals for Human Use. Available: https:// www.ich.org/ [Accessed 02 Dec 2020]

2 World Health Organisation good regulatory practices for regulatory oversight of medical products, draft for consultation August 2020 , working document QAS/16.686/Rev.3. Available: https://www. who.int/docs/default-source/medicines/norms-and-standards/ current-projects/qas16-686-rev-3-good-regulatory-practicesmedical-products.pdf?sfvrsn=ccb041db_2 [Accessed 02 Dec 2020].

3 Guzman J, O'Connell E, Kikule K, et al. The WHO global benchmarking tool: a game changer for strengthening national regulatory capacity. BMJ Glob Health 2020;5:e003181.

4 COVID-19 Dashboard by the Center for Systems Science and Engineering at Johns Hopkins University. Available: https:// coronavirus.jhu.edu/map.html [Accessed 02 Dec 2020].

5 World Health Organization coronavirus disease dashboard. Available: https://covid19.who.int/ [Accessed 02 Dec 2020].

6 World Health Organization triple billion dashboard. Available: https:// www.who.int/data/triple-billion-dashboard [Accessed 02 Dec 2020].

7 O'Brien J, Lumsden RS, Diehl DH, et al. Building a better approach for the benefit of patients: 10 pillars to strengthen regulatory review systems globally. Ther Innov Regul Sci 2020;54:283-92.

8 European Medicines Agency to issue electronic certificates for medicines, 2020. Available: https://www.ema.europa.eu/en/news/ ema-issue-electronic-certificates-medicines [Accessed 02 Dec 2020].

9 Health Canada. Stakeholder Instructions: requesting a certificate of a pharmaceutical product and good manufacturing practice certificate during COVID-19, 2020.

10 International Coalition of Medicines Regulatory Authorities statement on COVID-19, 2020. Available: http://icmra.info/drupal/en/covid-19 [Accessed 02 Dec 2020].

11 International Coalition of Medicines Regulatory Authorities statement on the value of regulatory reliance, 2020. Available: http://www. icmra.info/drupal/en/strategicinitatives/reliance/statement [Accessed 02 Dec 2020].

12 21st World Health Organization regulatory update on COVID-19, 2020. Available: https://www.who.int/publications/m/item/21st-whoregulatory-update-on-covid-19 [Accessed 02 Dec 2020].

13 Gostin LO, Wood AJ, Cuff PA. Regulating medicines in a globalized world with increased recognition and reliance among regulators: a national academies report. JAMA 2020;324:145-6.

14 MacKenzie R, Honig P, Sewards J, et al. COVID-19 must catalyse changes to clinical development. Nat Rev Drug Discov 2020;19:653-4.

15 IFPMA. Biopharmaceutical industry support EU regulators exceptional transparency measures and call other regulatory authorities to follow suit to help ensure confidence in the science and the decision making, 2020. Available: https://www.ifpma.org/ resource-centre/biopharmaceutical-industry-support-eu-regulatorsexceptional-transparency-measures-and-call-other-regulatoryauthorities-to-follow-suit-to-help-ensure-confidence-in-the-scienceand-the-decision-making/ [Accessed 02 Dec 2020].

16 Stewart J, Honig P, AlJuburi L. COVID-19: a catalyst to accelerate global regulatory transformation. Clin. Pharmacol. Ther. 2020; Published online ahead of print. 